\title{
Analysis of transfusion requirements and costs before and after the introduction of thromboelastometry guided factor concentrate based algorithm for the therapy of coagulopathy in massive bleeding
}

\author{
I Zykova*, P Sedlak, D Morman \\ From ESICM LIVES 2015 \\ Berlin, Germany. 3-7 October 2015
}

\section{Introduction}

Our ICU is a general mixed ICU with 9 beds in a trauma centre. We admit over 300 patients/year. We have started using thromboelastometry (ROTEM) in 2009. Thromboelastometry is used to guide the therapy of massive bleeding and therapy of coagulopathy in ICU patients. The usage of thromboelastometry has been increasing since 2009 and in January 2014 we have implemented POC thromboelastometry guided factor concentrate based coagulation algorithm for the treatment of coagulopathy in massive bleeding [1].

\section{Objectives}

Analysis of transfusion requirements of packed red blood cells (PRBC), plasma (FFP), platelet concentrates and the usage of fibrinogen and prothrombin complex concentrate (PCC) in ICU patients before and after the introduction of thromboelastometry guided factor concentrate based coagulation algorithm for the treatment of coagulopathy in massive bleeding and its influence on cost of therapy.

\section{Methods}

Retrospective analysis of the utilisation of blood products (PRBC,FFP, platelet concentrates in therapeutic doses) and fibrinogen and PCC before and after the introduction of thromboelastometry guided factor concentrate based coagulation algorithm.

\footnotetext{
Regional Hospital Liberec, Department of Anesthesiology and Intensive Care
} Medicine, Liberec, Czech Republic

(c) 2015 Zykova et al.; This is an Open Access article distributed under the terms of the Creative Commons Attribution License (http:// creativecommons.org/licenses/by/4.0), which permits unrestricted use, distribution, and reproduction in any medium, provided the original work is properly cited.

\section{Results}

The usage of all allogenic blood products has decreased in our unit after the introduction of thromboelastometry guided factor concentrate based coagulation algorithm by $46,7 \%$.

The reduction of PRBC was $16,6 \%$, platelet concentrate usage decreased by $43,6 \%$ and FFP usage decreased by $81,8 \%$.

The usage of fibrinogen and PCC has increased after the implementation of algorithm.

The cost of therapy of bleeding and coagulopathy in fibrinogen and PCC) has not significantly changed after the implementation of algorithm.

\section{Conclusions}

We have achieved a major reduction in allogenic blood products after the introduction of a thromboelastometry guided factor concentrate based coagulation algorithm in our intensive care unit. The usage of fibrinogen and PCC has increased, but the cost has not significantly changed. Implementation of thromboelastometry guided factor concentrate based coagulation algorithm reduces the exposure of intensive care patients to allogenic blood products and does not increase cost of therapy of bleeding and coagulopathy.

\section{Grant Acknowledgment}

Our study was supported by a grant from Scientific Board of Regional Hospital Liberec our ICU (cost of PRBC, FFP, platelet concentrates, 

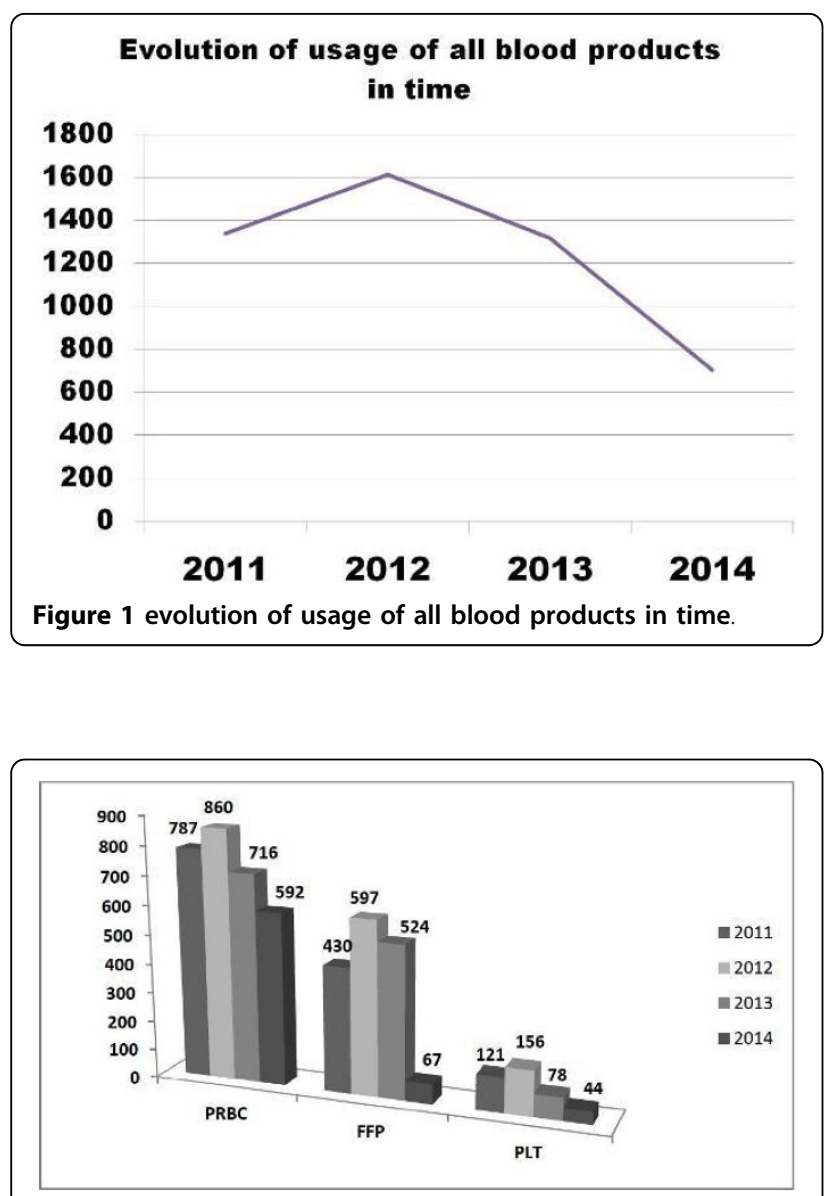

Figure 2 evolution in usage of PRBC,FFP and platelets

Table 1

\begin{tabular}{lll}
\hline & fibrinogen $\mathbf{( g )}$ & PCC (doses) \\
\hline 2013 & 146 & 91 \\
\hline 2014 & 257 & 128 \\
\hline [usage of fibrinogen and PCC]
\end{tabular}

Published: 1 October 2015

\section{Reference}

1. Schochl H, Maegele M, Solomon C, Gorlinger K: Voelckel: Early and individualized goal-directed therapy for trauma-induced coagulopathy. Scan I Trauma, Resuscitation and Emergency Medicine 2012, 20:15.

doi:10.1186/2197-425X-3-S1-A914

Cite this article as: Zykova et al:: Analysis of transfusion requirements and costs before and after the introduction of thromboelastometry guided factor concentrate based algorithm for the therapy of

coagulopathy in massive bleeding. Intensive Care Medicine Experimental 2015 3(Suppl 1):A914.

\section{Submit your manuscript to a SpringerOpen ${ }^{\circ}$ journal and benefit from:}

- Convenient online submission

- Rigorous peer review

- Immediate publication on acceptance

- Open access: articles freely available online

- High visibility within the field

- Retaining the copyright to your article

Submit your next manuscript at $>$ springeropen.com 